\title{
Economic efficiency of sanitary treatment of milking equipment using ecologically safe detergent-sanitizers Sanimol $L$ and Sanimol K
}

\author{
Kryvokhyzha Ye. ${ }^{1}$, Osadchuk V. ${ }^{2}$ \\ ${ }^{1}$ Institute of agroecology and nature management of NAAS, 12 Metrolohichna Str., Kyiv, 03143, Ukraine, \\ ${ }^{2}$ Bukovyna State agricultural research Station of the Institute of Agriculture of Carpathian Region of NAAS, 21A \\ Bohdana Kryzhanivskoho Str., Chernivtsi, 58026, Ukraine; e-mail: ' 1 ye.kryvokhyzha@ukr.net, ${ }^{2}$ buksaes@meta.ua \\ ORCID: ${ }^{1}$ 0000-0001-7270-6529, ${ }^{20000-0002-6607-6310 ~}$
}

Goal. To determine the economic efficiency of sanitation of milking and dairy equipment with the use of new detergents Sanimol L and Sanimol K. Methods. General scientific methods are used: analysis and synthesis, comparison, and theoretical generalization. A direct calculation of the difference in the cost of similar funds is also made. Results. It is determined that the total estimated economic effect per 100 lactating cows during sanitation of 5 portable milking machines three times a day and milk cooler once a day with Sanimol $L$ and Sanimol $K$ during the year will be UAH 21,097 compared to CircoSuper AF and Sidmax. The economic effect obtained due to the increase of microbiological indicators of milk quality as a result of sanitary treatment of milking equipment with Sanimol $L$ and Sanimol $\mathrm{K}$ is calculated for 100 cows for 3 times milking with portable milking machines. The milk yield for one lactating cow was $4,500 \mathrm{~kg} /$ year. Before the introduction of sanitary treatment of milking equipment with Sanimol $\mathrm{L}$ and Sanimol K, the farm received the grade I milk which worth $8.4 \mathrm{UAH} / \mathrm{kg}$. The use of these preparations made it possible to obtain and deliver milk to the processing plant of the extra grade for $9.8 \mathrm{UAH} / \mathrm{kg}$. Annual economic effect - UAH 624097.2. Conclusions. The use of Sanimol L for sanitary treatment of milking equipment is $1.3-1.8$ times more cost-effective compared to CircoSuper AF, and Sanimol K - 3.8 - 4 times more than Sidmax. The annual economic effect due to the use of Sanimol $\mathrm{L}$ and Sanimol $\mathrm{K}$ for sanitation of milking equipment and dairy equipment on dairy farms with a population of 100 cows will amount to UAH 624097.2.

Key words: cost calculation, costs, microbiological indicators, milk grade.

DOI: https://doi.org/10.31073/agrovisnyk202011-09

Upon receipt of milk basic source of its microbial contamination is insufficiently cleaned milking equipment [1]. The remains of milk and water for rinsing on internal surfaces milking and dairy equipment support the development of microorganisms [2]. Insufficient cleaning and disinfection of milking and dairy equipment allows microorganisms remain, reproduce and grow on their internal surfaces. This results to increase of number of microorganisms in milk [3]. An important condition for receipt of milk of sort extra is the use to sanitizing milking equipment of cleaningdisinfecting agents providing its proper cleanliness in accord with uniform norm with numbers of microbes of wash off up to $500 \mathrm{CFU} / \mathrm{cm}^{3}$ [4]. At the same time besides ensuring the normative cleanliness of milking and dairy equipment cleaning-disinfecting agents must have such competitive advantages as: ecological safety and a little lower cost compared with analogical products. Taking this into account, determination of economic efficiency use cleaning-disinfecting agents to sanitizing milking equipment is one of the important tasks.

Analysis of recent research and publications. Creating of cleaning-disinfecting agents to sanitizing of milking and dairy equipment were engaged in A.G. Khramtsov [5], J. Berard [6], F. Gelmi [7] et al. Questions related to assessment of effectiveness of cleaning-disinfecting agents to sanitizing of milking equipment reflected in the study of such scientists as: N.N. Laushkina [8], M.M. Karpenya [9], M.A. Sergeeva [10], A.R. Monken [11] et al. However, in scientific literature enough little attention is paid to such question, as determination of economic efficiency of using of cleaning-disinfecting agents to sanitizing of milking equipment.

Goal of researches. Determination of economic efficiency of sanitizing of milking and dairy equipment at application of new cleaning-disinfecting agents Sanimol L and Sanimol K.

Materials and methods of researches. In preparing of article following general scientific methods were used, as analysis and synthesis (when determining of cost of sanitizing of milking equipment when using of cleaningdisinfecting agents), comparisons (to determine more economically of effective agents) and theoretical generalization (applied for formulation of conclusions).

Economic efficiency of application of agents Sanimol $\mathrm{L}$ and Sanimol $\mathrm{K}$ to sanitizing of milking equipment were determined of the difference of cost of analogical agents and by calculation the increases of microbiological indexes of quality of milk obtained as a result of realization of sanitizing of milking equipment by these agents.

Results of researches. Calculation of cost of sanitizing of milking equipment when using agents of Sanimol $\mathrm{L}$ and Sanimol $\mathrm{K}$ have conducted in comparative aspects to available on the Ukrainian market agents, in particular CircoSuper AF and Sidmax. Analysis of price lists of different firms on realization of cleaning-disinfecting agents on 1.02.2020 showed that price of CircoSuper AF, on average, is 36 hrivnas and Sidmax - 100.0 hrivnas. The cost of agents Sanimol L and Sanimol K is 20 and 25 hrivnas respectively. 
First of all, were conducted calculation of the value of alkaline agents. For sanitizing of portable milking machines, cost of preparation 100 liters of $0.7 \%$ of working solution of agent of Sanimol $L$ is 14.0 hrivnas. The cost of preparation 100 liters of $0.5 \%$ of working solution of agent of CircoSuper AF - 18.0 hrivnas. Economic efficiency is 4.0 hrivnas (18-14). Expenses on sanitizing of the five portable milking machines the agent Sanimol $\mathrm{L}$ is 1.4 hrivnas and the agent CircoSuper AF -1.8 hrivnas. Expenses on sanitizing of the five portable milking machines the agent Sanimol $L$ at milking three times a day throughout the year is 1533.0 hrivnas and CircoSuper AF - 1971.0 hrivnas. Economic efficiency when applying for sanitizing of milking equipment of agent Sanimol $L$ throughout the year was 438.0 hrivnas (Table 1).

\section{Cost of one sanitizing of milking equipment with alkaline agents}

\begin{tabular}{|c|c|c|c|c|c|}
\hline \multirow{2}{*}{$\begin{array}{c}\text { Name of the } \\
\text { agent }\end{array}$} & \multirow{2}{*}{$\begin{array}{l}\text { The concentra- } \\
\text { tion, } \%\end{array}$} & \multirow{2}{*}{$\begin{array}{l}\text { The quantity of } \\
\text { working solution, } \\
\text { liters }\end{array}$} & \multicolumn{3}{|c|}{ The cost of sanitizing, hrivnas } \\
\hline & & & $\begin{array}{l}\text { five portable milking } \\
\text { machines }\end{array}$ & milk pipeline & milk cooler \\
\hline \multirow[t]{3}{*}{ Sanimol L } & 0.7 & 10 & 1.4 & - & - \\
\hline & 0.5 & 100 & - & 10 & - \\
\hline & 1.0 & 50 & - & - & 10 \\
\hline \multirow[t]{3}{*}{ CircoSuper AF } & \multirow{2}{*}{0.5} & 10 & 1.8 & - & - \\
\hline & & 100 & - & 18 & - \\
\hline & 1.0 & 50 & - & - & 18 \\
\hline
\end{tabular}

For sanitizing of milking installation with milk pipeline, cost of preparation 100 liters of $0.5 \%$ of working solution of agent of Sanimol $L$ is 10.0 hrivnas and 100 liters of $0.5 \%$ of working solution of analogical agent -18.0 hrivnas. Economic efficiency will be -8.0 hrivnas (18.0-10.0). Expenses on sanitizing of milking installation with milk pipeline the agent Sanimol $L$ is 10.0 hrivnas and the agent CircoSuper AF - 18.0 hrivnas. Expenses on sanitizing of milking installation with milk pipeline at milking three times a day throughout the year is 10950.0 hrivnas and 19710.0 hrivnas respectively. Economic efficiency is 8760.0 hrivnas (Table 2 ).

\section{Cost of using alkaline agents for sanitizing of milking equipment throughout the year}

\begin{tabular}{|c|c|c|c|c|c|}
\hline \multirow{2}{*}{$\begin{array}{l}\text { Name of the } \\
\text { agent }\end{array}$} & \multirow{2}{*}{$\begin{array}{l}\text { The concentra- } \\
\text { tion, } \%\end{array}$} & \multirow{2}{*}{$\begin{array}{l}\text { The quantity of } \\
\text { working solution, } \\
\text { thousands liters }\end{array}$} & \multicolumn{3}{|c|}{ The cost of sanitizing, thousands hrivnas } \\
\hline & & & $\begin{array}{l}\text { five portable milking } \\
\text { machines }\end{array}$ & milk pipeline & milk cooler \\
\hline \multirow[t]{3}{*}{ Sanimol L } & 0.7 & 11.0 & 1.5 & - & - \\
\hline & 0.5 & 109.5 & - & 11.0 & - \\
\hline & 1.0 & 54.8 & - & - & 11.0 \\
\hline \multirow[t]{3}{*}{ CircoSuper AF } & \multirow{2}{*}{0.5} & 11.0 & 2.0 & - & - \\
\hline & & 109.5 & - & 19.7 & - \\
\hline & 1.0 & 54.8 & - & - & 19.7 \\
\hline
\end{tabular}

For sanitizing of milk cooler, cost of preparation 100 liters of $1.0 \%$ of working solution of agent of Sanimol $\mathrm{L}$ is 20.0 hrivnas. The cost of preparation 100 liters of $1.0 \%$ of working solution of agent of CircoSuper AF - 36.0 hrivnas. Economic efficiency is 16.0 hrivnas (36.0-20.0). Expenses on sanitizing of milk cooler 10.0 hrivnas and 18.0 hrivnas. Expenses on sanitizing of milk cooler throughout the year is 3650.0 hrivnas and 6570.0 hrivnas. Economic efficiency is 2920.0 hrivnas.

Thus, the general supposed economic effect on 100 lactating cows when sanitizing of five portable milking machines three times per day and milk cooler once a day agent of Sanimol $\mathrm{L}$ in a year will be 3358.0 hrivnas.

Calculated cost of the application of acidic agents for sanitizing of portable milking machines. Preparation of 100 liters of $0.5 \%$ of working solution of agent of Sanimol K costs 12.5 hrivnas. The cost of preparation 100 liters of $0.5 \%$ of working solution of agent of Sidmax - 50.0 hrivnas. Economic efficiency is 37.5 hrivnas $(50.0-12.5)$. Expenses on sanitizing of the five portable milking machines the agent Sanimol K is 1.3 hrivnas and the agent Sidmax $-5,0$ hrivnas. Expenses on sanitizing of the five portable milking machines the agent Sanimol $\mathrm{K}$ at milking three times a day throughout the year is 1423.5 hrivnas and the agent Sidmax -5475.0 hrivnas. Economic efficiency when applying for sanitizing of milking equipment of agent Sanimol K throughout the year was 4051.5 hrivnas (Table 3). 


\section{Cost of one sanitizing of milking equipment with acid agents}

\begin{tabular}{|c|c|c|c|c|c|}
\hline \multirow{2}{*}{$\begin{array}{l}\text { Name of the } \\
\text { agent }\end{array}$} & \multirow{2}{*}{$\begin{array}{l}\text { The concentra- } \\
\text { tion, } \%\end{array}$} & \multirow{2}{*}{$\begin{array}{l}\text { The quantity of } \\
\text { working solution, } \\
\text { liters }\end{array}$} & \multicolumn{3}{|c|}{ The cost of sanitizing, hrivnas } \\
\hline & & & $\begin{array}{l}\text { five portable milking } \\
\text { machines }\end{array}$ & milk pipeline & milk cooler \\
\hline \multirow[t]{3}{*}{ Sanimol K } & \multirow{2}{*}{0.5} & 10 & 1.3 & - & - \\
\hline & & 100 & - & 12.5 & - \\
\hline & 1.0 & 50 & - & - & 12.5 \\
\hline \multirow[t]{3}{*}{ Sidmax } & \multirow{2}{*}{0.5} & 10 & 5.0 & - & - \\
\hline & & 100 & - & 50.0 & - \\
\hline & 1.0 & 50 & - & - & 50.0 \\
\hline
\end{tabular}

For sanitizing of milking installation with milk pipeline, cost of preparation 100 liters of $0.5 \%$ of working solution of agent of Sanimol K is 12.5 hrivnas and 100 liters of $0.5 \%$ of working solution of analogical agent is 50.0 hrivnas. Economic efficiency will be -37.5 hrivnas (50.0-12.5). Expenses on sanitizing of milking installation with milk pipeline the agent Sanimol K is 12.5 hrivnas and the agent Sidmax - 50.0 hrivnas. Expenses on sanitizing of milking installation with milk pipeline at milking three times a day throughout the year is 13687.5 hrivnas and 54750.0 hrivnas respectively. Economic efficiency is 41062.5 hrivnas (Table 4 ).

\section{Cost of using acidic agents for sanitizing of milking equipment throughout the year}

\begin{tabular}{|c|c|c|c|c|c|}
\hline \multirow{2}{*}{$\begin{array}{c}\text { Name of the } \\
\text { agent }\end{array}$} & \multirow{2}{*}{$\begin{array}{l}\text { The concentra- } \\
\text { tion, } \%\end{array}$} & \multirow{2}{*}{$\begin{array}{l}\text { The quantity of } \\
\text { working solution, } \\
\text { thousands liters }\end{array}$} & \multicolumn{3}{|c|}{ The cost of sanitizing, thousands hrivnas } \\
\hline & & & $\begin{array}{l}\text { five portable milking } \\
\text { machines }\end{array}$ & milk pipeline & milk cooler \\
\hline \multirow[t]{3}{*}{ Sanimol K } & \multirow{2}{*}{0.5} & 11.0 & 1.4 & - & - \\
\hline & & 109.5 & - & 13.7 & - \\
\hline & 1.0 & 54.8 & - & - & 13.7 \\
\hline \multirow[t]{3}{*}{ Sidmax } & \multirow[b]{2}{*}{0.5} & 11.0 & 5.5 & - & - \\
\hline & & 109.5 & - & 54.8 & - \\
\hline & 1.0 & 54.8 & - & - & 54.8 \\
\hline
\end{tabular}

For sanitizing of milk cooler, cost of preparation 100 liters of $1.0 \%$ of working solution of agent of Sanimol $\mathrm{K}$ is 25.0 hrivnas. The cost of preparation 100 liters of $1.0 \%$ of working solution of agent of Sidmax -100.0 hrivnas. Economic efficiency is 75.0 hrivnas (100.0-25.0). Expenses on sanitizing of milk cooler is 12.5 hrivnas and 50.0 hrivnas. Expenses on sanitizing of milk cooler throughout the year is 4562.5 hrivnas and 18250.0 hrivnas. Economic efficiency is 13687.5 hrivnas.

Thus, the general supposed economic effect on 100 lactating cows when sanitizing of five portable milking machines three times per day and milk cooler once a day agent of Sanimol K in a year will be 17739.0 hrivnas.

Economic efficiency of application of agents Sanimol L and Sanimol K was calculated on 100 cows at three times milking by portable milking machines. Milk yield per lactating cow was $4500 \mathrm{~kg}$ per year. On the farm before the introduction of sanitizing of milking and dairy equipment by agents of Sanimol $\mathrm{L}$ and Sanimol $\mathrm{K}$ received milk first class by a cost a 8.4 hrivnas per $1 \mathrm{~kg}$. The use of these agents allowed to get and deliver milk to the processing plant sort extra, at a cost of $1 \mathrm{~kg}-9.8$ hrivnas.

The economic effect a consequence of improved microbiological indicators of quality of freshly milked milk as a result of realization of sanitizing of milking equipment agents of Sanimol L and Sanimol K (Es) was calculated according to the formula:

$$
E s=Q m \times\left(P_{1}-P_{2}\right)-E s
$$

where: $\mathrm{Qm}$ - quantity of freshly milked milk of sort extra, (kg);

$P_{1}$ and $P_{2}-$ prices on realization obtained of milk extra and first sorts respectively, (hrivnas);

Es - expenses on realization of sanitizing of milking machines, milk containers and milk cooler, (hrivnas).

$$
\mathrm{Es}=450000.0 \times(9.8-8.4)-5902.8=624097.2 \text { hrivnas. }
$$

The annual economic effect as the result of using agents of Sanimol $L$ and Sanimol $K$ to sanitize of milking and dairy equipment on dairy farms with number of 100 cows will be 624097.2 hrivnas. 


\section{Conclusion}

Determined the economic efficiency of application of new agents Sanimol $L$ and Sanimol $K$ to sanitizing of milking equipment. The general supposed economic effect when used cleaning-disinfecting agents Sanimol $L$ and Sanimol $\mathrm{K}$ for milking installation with milk pipeline three times per day and milk cooler once a day in a year will be 66430.0 hrivnas compared to CircoSuper AF and Sidmax. It is established, that application of agent of Sanimol $L$ is economically advantageous by 1.3-1.8 times compared with CircoSuper AF. Use of agent of Sanimol L by 3.8-4.0 times cheaper relative to Sidmax. The annual economic effect as the result of using agents of Sanimol $L$ and Sanimol $K$ to sanitize of milking equipment on dairy farms with number of 100 cows will be 624097.2 hrivnas.

\section{References}

1. Robinson, R.K. (2002). Dairy microbiology handbook: the microbiology of milk and milk products. 3rd ed. New York: John Wiley and Sons.

2. Murphy, S.C., \& Boor, K.J. (2000). Trouble-shooting sources and causes of high bacteria counts in raw milk. Dairy, Food and Environmental Sanitation, 20 (8), 606-611.

3. Bava, L. Zucali, M., Brasca, M., Zanini, L., Sandrucci, A. (2009). Efficiency of cleaning procedure of milking equipment and bacterial quality of milk. Italian Journal of Animal Science, 8, 2, 387-389.

4. Laiter-Moskaliuk, S.V., Reshetnyk, A.O., Horiuk, V.V., \& Perkii, Yu.B. (2016). Rozrobka rezhymiv sanitarnoi obrobky doilnoho ustatkuvannia kyslotnym zasobom «TDS» [Development of modes of milking equipment sanitization with the help of «TDS» acid detergent-sanitizer]. Scientific Messenger of LNU of Veterinary Medicine and Biotechnologies, 18, 1 (65), 2, 188-192. [In Ukrainian].

5. Khramtsov, A.G., Anisimov, G.S., Anisimov, S.V., Serov, A.V., Blinov, A.V., \& Blinova, A.A. Patent. no. 2654465 C1 Russian Federation, MPK(2006. 01) C11D 1/62, C11D 1/66, C07F 1/10, C11D 3/384. Moyushchedezinfitsiruyushchee sredstvo dlya predpriyatiy molochnoy promyshlennosti [Detergent sanitizer for dairy companies]; Applicant and Patent Attorney Federal State Autonomous Educational Institution of Higher Education "North Caucasian Federal University"; no. 2017119808; stated 06.06.2017; posted by 18.05.2018. 12 p. [In Russian].

6. Berard, J., Bardoneschi, G., Bechenne, L., \& Laroche, B. Patent World Intellectual Property Organization no. WO 91/18080, IPC C11D 3/06, 1/02. Mixture for cleaning and disinfecting milking equipment; Applicant and Patent Attorney Henkel Kommanditgesellschaft auf Aktien; no. PCT/EP91/00846; stated 06.05.1991; posted by 28.11.1991. $15 \mathrm{p}$.

7. Gelmi, F., \& Venturin,i M. European patent no. EP 2915874 A1, IPC (2006. 01) C11D 3/395, C11D 3/04, C11D 3/08, C11D 3/12. № 14157434.3. Composition for washing and sanitizing food production plants; Applicant and Patent Attorney I.C.F S.r.l. 26020 Palazzo Pignano; no. 14157434.3; stated 03.03.2014 ; posted by 09.09.2015. $8 \mathrm{p}$.

8. Laushkina, N.N., \& Surkov, R.A. (2017). Otsenka sanitarno-bakteriologicheskogo sostoyaniya doilnykh apparatov pri ispolzovanii moyushche-dezinfitsiruyushchikh sredstv marki «Katril» i Rom-fos [Evaluation of sanitarybacteriological condition of milking machines when use washing and disinfectants-brand "Catril" and Rom-phos]. Bulletin of Orel State Agrarian University, 3 (66), 104-109. [In Russian].

9. Karpenya, M.M., Podrez, V.N., Karpenya, A.M., \& Shaura, T.A. (2018). Effektivnost ispolzovaniya raznykh moyushche-dezinfitsiruyushchikh sredstv pri proizvodstve dobrokachestvennogo moloka [Efficiency of different detergents and disinfectants in the production of quality milk]. Scientific notes of the educational institution Vitebsk State Academy of Veterinary Medicine, 54, 4, 164-168. [In Russian].

10.Sergeeva, M.A., \& Shchiptsova, N.V. (2017). Effektivnost ispolzovaniya dezinfitsiruyushchikh sredstv pri proizvodstve kachestvennogo syrogo moloka [Efficiency of using desinfectants in qualitaty raw milk production]. Bulletin of Altai State Agricultural University, 6 (152), 122-126. [In Russian].

11. Monken, A.R. Patent United States no. US 6,472,199 B1, IPC C12S 9/00. Method of cleaning dairy pipelines using enzyme pretreatment; Applicant and Patent Attorney West Agro, Inc.; no. 09.1825,749; stated 04.04.2001; posted by 29.10.2002. $5 \mathrm{p}$.

12.Vinokurov, V.V. (1982). Sostoyanie i perspektivy ekonomicheskikh issledovaniy $v$ veterinarii [The state and prospects of economic research in veterinary medicine]. Moscow: All-Union Scientific Research Institute of Information and Technical-Economic Research on Agriculture. [In Russian]. 